\section{Site-Directed Mutagenesis of Large (13-kb) Plasmids in a Single-PCR Procedure}

BioTechniques 29:976-978 (November 2000)

Although there are many methods for site-specific mutagenesis, most are only applicable for short $(<7-\mathrm{kb})$ plasmids. The few methods that have been developed for longer plasmids are complicated procedures that involve multiple PCR steps or complex recombination and ligation reactions (2,4-6). Here, we provide a simple single-PCR procedure for site-specific mutagenesis of long plasmids (13 kb), even with primers having strong secondary structure.

Our protocol is a modification of the QuickChange $^{\mathrm{TM}}$ Site-Directed Mutagenesis (SQM) kit (Stratagene, La Jolla, CA, USA) method originally published by Weiner and Costa (7). The pair of complementary oligonucleotides containing the desired mutation must (i) be 30-45 bases long, (ii) contain at least one $\mathrm{C}$ or $\mathrm{G}$ base at each terminus, (iii) have melting temperatures of at least $78^{\circ} \mathrm{C}$ and (iv) have the mutations in the middle of the primers so that there is at least 10 bases of sequence complementary to the parental sequence on either side. The oligonucleotides must also be purified by either SDS-PAGE or HPLC. Using unpurified oligonucleotides drastically reduces mutagenesis efficiency (data not shown). In addition, for mutagenesis of large plasmids, we found it is optimal to design primers that have little or no secondary structure. This is an important criterion that is not accounted for in the SQM kit.

The PCR mixture contains 150 ng each oligonucleotide, $10 \mathrm{ng}$ template plasmid DNA, $200 \mu \mathrm{M}$ dNTPs, $2.5 \mathrm{U}$ PfuTurbo ${ }^{\mathrm{TM}}$ DNA polymerase (Stratagene) and the buffer supplied with the polymerase in a total volume of $50 \mu \mathrm{L}$. PCR is performed under the following conditions: denaturation at $95^{\circ} \mathrm{C}$ for 30 $\mathrm{s}$, followed by 16 cycles of denaturation at $95^{\circ} \mathrm{C}$ for $30 \mathrm{~s}$, annealing at $55^{\circ} \mathrm{C}$ for $1 \mathrm{~min}$ and extension at $68^{\circ} \mathrm{C}$ for 2 $\mathrm{min} / \mathrm{kb}$ template (which is identical to that described in the SQM kit). A portion of the PCR mixture is then exam- ined by agarose gel electrophoresis to determine whether the correct-sized product was obtained. If these PCR conditions did not generate the correctsized product, then several parameters of the PCR can be altered to produce the correct product.

When the correct-sized product is obtained, then the PCR product $(50 \mu \mathrm{L})$ is incubated with $20 \mathrm{UDpnI}$ for $2 \mathrm{~h}$ at $37^{\circ} \mathrm{C}$. This latter step is critical because it preferentially digests the parental DNA (which is methylated and therefore is subject to DpnI digestion) and thereby increases dramatically the frequency of clones with the desired mutation (3). Five microliters of the DNA are then transformed into $100 \mu \mathrm{L}$ competent Top $10^{\circledR}$ E. coli cells (Invitrogen, Carlsbad, CA, USA).

To test the method, we used a 6.2-kb plasmid $(\beta-299)$ and a $13-k b$ plasmid $(\beta-290)$, which contain a 3.2-kb SalI/ BamHI mouse T-cell receptor genomic fragment inserted into the 3-kb Bluescript $^{\circledR}(\mathrm{KS}+)$ vector (Stratagene) and pHßAPr1-neo vector (EV-107) of approximately $9.8 \mathrm{~kb}$, respectively (1). The primers used for mutagenesis are shown in Table 1.

There are three major differences between our protocol and that of the SQM kit that we found were critical for generating large PCR products (13 kb) mutated at high efficiency. (i) The inclusion of 5\%-10\% dimethyl sulfoxide (DMSO) in the PCR mixture was often necessary when using primers with strong secondary structure and/or when the plasmid template was greater than $6 \mathrm{~kb}$. (ii) The temperature of the annealing step of the PCR sometimes needed to be altered depending on the secondary structure of the oligonucleotides used for amplification. We found that annealing temperatures between $55^{\circ} \mathrm{C}$ and $72^{\circ} \mathrm{C}$ generated visible products for most oligonucleotides. (iii) We used excess DpnII (20 $\mathrm{U})$ for a longer incubation (2 h) than suggested by the SQM kit to completely digest the parental DNA. We found that this step was critical for providing a higher efficiency of mutagenesis (95\%-100\%) of large plasmids (13 kb) compared to the more modest mutagenesis efficiency (about 80\%) achieved by the standard SQM kit for small- and intermediate-sized plasmids.

After following the procedure de- scribed above, we sequenced plasmid DNAs prepared from individual bacterial colonies. We found that the 6.2-kb plasmid template efficiently generated PCR product, and least $92 \%$ of the DNA clones contained the desired mutation (Table 2). In contrast, PCR conditions required to amplify the $13-\mathrm{kb}$ plasmid typically had to be modified to generate the correct-sized PCR product. For the oligonucleotide pair P1, each primer of which has weak secondary structure, we found that it was only necessary to include $10 \%$ DMSO to generate the correct-sized PCR product. [Secondary structure can be determined by using the formula obtained from the Genosys Web site (www. genosys.com)]. Ninety-five percent of the clones obtained from this PCR product were correctly mutagenized (Table 2). When we used oligonucleotide pairs P2 and P3, which have moderate and strong secondary structure, respectively, we could not generate detectable PCR products even with DMSO. To obtain the correct-sized PCR product with these oligonucleotides, we raised the annealing temperature to $72^{\circ} \mathrm{C}\left(8^{\circ} \mathrm{C}-10^{\circ} \mathrm{C}\right.$ lower than the $\mathrm{T}_{\mathrm{m}}$ of the primers) and increased the denaturation time to $45 \mathrm{~s}$ per cycle. These P2 and P3 PCR products also generated a high percentage of correctly mutagenized clones (Table 2). However, we found that less PCR product was generated using moderate-tostrong secondary structure primers, as compared with using primers with weak secondary structure (data not shown). Consistent with the generation of less PCR product, we found that transformation of this DNA yielded 7-15 times fewer colonies.

Our method does not require using the SQM kit. Although the kit is useful for beginners, we found that the kit did not work with large (>10 kb) plasmids, according to the manufacturer's protocol (data not shown). Furthermore, our method is cheaper and requires less specialized reagents. For example, the kit includes Epicurian Coli ${ }^{\circledR}$ XL1-Blue Supercompetent bacterial cells (Stratagene), which are expensive, sensitive to freezing and thawing, and require particular conditions for transformation [e.g., the use of $\mathrm{NZY}^{+}$broth (Stratagene) and Falcon 2059 tubes (Becton 
Table 1. Oligonucleotide Primers

\begin{tabular}{|c|c|c|c|c|}
\hline $\begin{array}{c}\text { Primer } \\
\left({ }^{\circ} \mathrm{C}\right) \text { Pairs }\end{array}$ & Primers & $\begin{array}{l}\text { Primer } \\
\text { Sequence }^{a} \\
\left(5^{\prime} \rightarrow 3^{\prime}\right)\end{array}$ & $\begin{array}{l}\text { Secondary } \\
\text { Structure }\end{array}$ & $\mathbf{T}_{\mathbf{m}}$ \\
\hline \multirow[t]{2}{*}{ P1 } & MDA519 & CCATGACTATGTADTGGTATCGGGCAGGACACGGGG & Weak & 79.9 \\
\hline & MDA520 & CCCCGTGTCCTGCCGATACCAHTACATATAGTCATGG & Weak & 79.9 \\
\hline \multirow[t]{2}{*}{$\mathrm{P} 2$} & MDA521 & СTCTCTCATTCTGGAGTVGGCTTCCCTTTCTCAGACAGC & Moderate & 80.5 \\
\hline & MDA522 & GCTGTCTGAGAAAGGGAAGCCBACTCCAGAATGAGAGAG & Moderate & 78.7 \\
\hline \multirow[t]{2}{*}{ P3 } & MDA540 & CAAGGCCCTCGAGGGCCTCCAGACCAAGC & Very strong & 82.3 \\
\hline & MDA541 & GCTTGGTCTGGAGGㅡC.TCGAGGGCCTTG & Very strong & 82.3 \\
\hline
\end{tabular}

Table 2. Generation of Mutant Clonesa

\begin{tabular}{|c|c|c|c|c|c|}
\hline $\begin{array}{l}\text { Primer } \\
\text { Pairs }\end{array}$ & $\begin{array}{l}\text { Template } \\
\text { Size }\end{array}$ & DMSO & $\begin{array}{c}\text { PCR } \\
\text { Conditions }\end{array}$ & Colonies & $\begin{array}{c}\text { Mutagenesis } \\
\text { Efficiency }\end{array}$ \\
\hline $\mathrm{P} 1$ & $6.2 \mathrm{~kb}$ & 0 & $S^{b}$ & 1320 & $100 \%$ \\
\hline P1 & $13 \mathrm{~kb}$ & 0 & $S$ & 0 & - \\
\hline $\mathrm{P} 1$ & $13 \mathrm{~kb}$ & $10 \%$ & $S$ & 360 & $95 \%$ \\
\hline P2 & $6.2 \mathrm{~kb}$ & 0 & $S$ & 1335 & $2 \%$ \\
\hline P2 & $13 \mathrm{~kb}$ & 0 & $S$ & 0 & - \\
\hline P2 & $13 \mathrm{~kb}$ & $10 \%$ & $\mathrm{~S}$ & 0 & - \\
\hline $\mathrm{P} 2$ & $13 \mathrm{~kb}$ & $10 \%$ & $M^{c}$ & 51 & $95 \%$ \\
\hline P3 & $6.2 \mathrm{~kb}$ & 0 & $\mathrm{~S}$ & 1500 & $96 \%$ \\
\hline P3 & $13 \mathrm{~kb}$ & 0 & $S$ & 0 & - \\
\hline P2 & $13 \mathrm{~kb}$ & $10 \%$ & $S$ & 0 & - \\
\hline P3 & $13 \mathrm{~kb}$ & $10 \%$ & $M$ & 24 & $100 \%$ \\
\hline \multicolumn{6}{|c|}{$\begin{array}{l}\text { a The transformation efficiencies of Top } 10 \text { cells with } \beta \text {-299 }(6.2-\mathrm{kb} \text { plasmid) and } \\
\beta-290 \text { (13-kb plasmid) were } 5 \times 10^{6} \text { and } 10^{6} / \mu \mathrm{g} \text {, respectively. After Dpnl diges- } \\
\text { tion and transformation, no colonies were observed on the ampicillin plates. } \\
\text { b } \mathrm{S} \text {, the standard protocol for PCR provided by SQM kit: preheating of the reac- } \\
\text { tion mixture to } 95^{\circ} \mathrm{C} \text { for } 30 \mathrm{~s} \text {, followed by } 16 \text { cycles of } 95^{\circ} \mathrm{C} \text { for } 30 \mathrm{~s}, 55^{\circ} \mathrm{C} \text { for } 1 \\
\text { min and } 68^{\circ} \mathrm{C} \text { for } 2 \mathrm{~min} / \mathrm{kb} \text { template. } \\
{ }^{\mathrm{C}} \mathrm{M} \text {, modified protocol: preheating of the reaction mixture to } 95^{\circ} \mathrm{C} \text { for } 3 \mathrm{~min} \text {, fol- } \\
\text { lowed by } 16 \text { cycles of } 95^{\circ} \mathrm{C} \text { for } 45 \mathrm{~s}, 72^{\circ} \mathrm{C} \text { for } 1 \mathrm{~min} \text { and } 68^{\circ} \mathrm{C} \text { for } 2 \mathrm{~min} / \mathrm{kb} \text { tem- } \\
\text { plate. }\end{array}$} \\
\hline
\end{tabular}

Dickinson, Franklin Lakes, NJ, USA)]. We found that Top10 E. coli cells made competent by standard laboratory protocols gave good results. Another commonly used $E$. coli strain, DH5 $\alpha^{\mathrm{TM}}$ (Life Technologies, Rockville, MD, USA), also was efficiently transformed and generated a high percentage of correctly mutagenized plasmid. Thus, our method is broadly applicable to several different E. coli strains; it is not only limited to Epicurian Coli XL1-Blue cells.
In conclusion, we provide here an inexpensive and convenient mutagenesis protocol. Our method permits very high-efficiency mutagenesis (> 95\%) of large (13-kb) plasmids, even with mutagenic oligonucleotides that have strong secondary structure.

\section{REFERENCES}

1.Carter, M.S., S. Li and M.F. Wilkinson. 1996. A splicing-dependent regulatory mechanism that detects translation signals. EMBO J. 15:5965-5975.

2.Gatlin, J., L.H. Campbell, M.G. Schmidt and S.J. Arrigo. 1995. BioTechniques 19:559-564.

3.Li, S. and M.F. Wilkinson. 1997. Site-directed mutagenesis: a two-step method using PCR and DpnI. BioTechniques 23:558-590.

4.Nadin-Davis, S.A. and S.C. Chang. 1998. Site-directed mutagenesis of large plasmids. BioTechniques 25:1014-1019.

5.Watkins, B.A., A.E. Davis, F. Cocchi and M.S. Reitz, Jr. 1993. A rapid method for sitespecific mutagenesis using larger plasmids as templates. BioTechniques 15:700-704.

6.Watkins, B.A. and M.S. Reitz. 1996. Using PCR for rapid site-specific mutagenesis in large plasmids. Methods Mol. Biol. 57:217227.

7.Weiner, M.P. and G.L. Costa. 1995. Rapid PCR site-directed mutagenesis, p. 613-621. In C.W. Dieffenbach and G.S. Dveksler (Eds.). PCR Primer: A Laboratory Manual. CSH Laboratory Press, Cold Spring Harbor, NY.

We thank Dr. Martha L Peterson (University of Kentucky Medical Center) for sharing the unpublished information. This research was supported by National Science Foundation grant no. MCB-9808936 and National Institutes of Health grant no. 
GM58595 to M.F.W. Address correspondence to Dr. Miles F. Wilkinson, Department of Immunology, Box 180, The University of Texas M.D. Anderson Cancer Center, 1515 Holcombe Blvd., Houston, TX 77030, USA. e-mail:mwilkins@notes.mdacc.tmc.edu

Received 11 April 2000; accepted 11 August 2000.

\section{Jun Wang and Miles F. Wilkinson The University of Texas M.D. Anderson Cancer Center Houston, TX, USA}

\section{Construction of a cDNA Encoding a Repetitive Amino Acid Sequence}

BioTechniques 29:978-981 (November 2000)

PCR is a powerful method with which to generate almost any desired cDNA sequence. Construction of cDNA fragments that encode repetitive amino acid sequences by PCR has proven problematic, however, because repetitive nucleotide primers tend to amplify undesired fragments because of their mis-annealing with the template. To overcome this problem, Dombrowski and Wright (2) developed a solid-phase gene assembly protocol, but this technique requires preparation of a solid-phase reaction system and thus cannot be routinely performed in most laboratories. Here, we describe a new strategy that makes use of standard PCR protocols, yet enables assembly of cDNAs encoding repetitive amino acid sequences.

The peptide unit Ala-Thr-Pro-AlaPro (ATPAP) is reported to be the shortest that can still function as an acceptor for $N$-acetylgalactosaminyltransferase-I (4). By introducing this peptide into a secretable form of fibroblast growth factor (FGF) (3) and expressing it in Chinese hamster ovary cells, we were able to produce FGF modified with a single $O$-glycan moi- ety (1). Subsequently, neo-O-glycosylated forms of FGF containing multiple $O$-glycans, similar to mucin-type glycoproteins, were created using two cDNAs encoding FGFs with 10 repeats of the pentapeptide $O$-glycosylation unit at the $\mathrm{N}$ - or $\mathrm{C}$-terminus. In this report, the creation of the $\mathrm{N}$-terminal modified form is described in detail.

The amino acids comprising the pentapeptide $O$-glycosylation unit, alanine, proline and threonine, are encod-

ed by codons GCX, CCX and ACX, respectively, where $\mathrm{X}$ is any nucleotide. We therefore designed four nucleotide cassettes that each encoded ATPAP and differed from one another at the last nucleotide for each codon (Figure 1A). To avoid mis-annealing the cassettes, they were linked together so that they encoded more than three repeats of the ATPAP unit (Figure 1B).

Generation of clones encoding the modified FGF entailed performing two

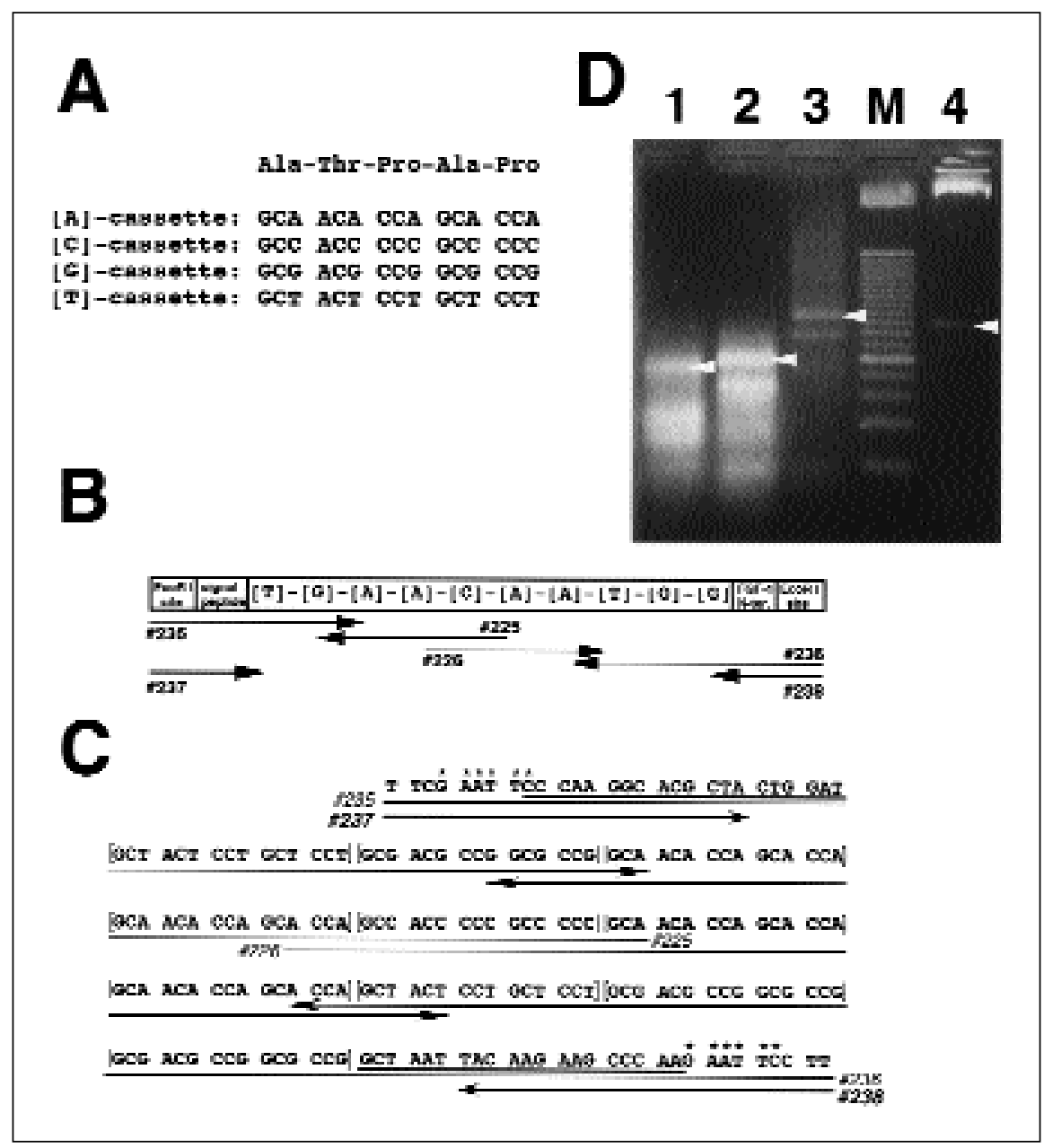

Figure 1. Construction of a cDNA encoding a repetitive amino acid sequence. (A) Four oligonucleotide cassettes, each encoding the pentapeptide $O$-glycosylation unit ATPAP. (B) Schematic diagram of the construction of a cDNA encoding the [ATPAP $]_{10}$ cassette, which is to be inserted between the signal peptide and the N-terminus of FGF-1. Each $O$-glycosylation unit is indicated by a bracket containing the symbol of the last nucleotide in each codon, as shown in panel A. PCR protocols were initially carried out separately using oligonucleotides \#235 and \#225 or \#226 and \#236 without a template. A mixture of the two reaction products was then subjected to PCR using primers \#237 and \#238. (C) Alignment of the primers with the completed sequence. The nucleotide sequences encoding the signal peptide and the FGF-1 N-terminus are underlined. The EcoRI recognition sites are indicated by asterisks. Primers are shown by arrows. (D) Agarose gel (4\%) electrophoresis of the PCR products and the enzyme digest of the final clone. Lane 1, the first PCR product obtained using \#235 and \#225 (106 bp); lane 2, the first PCR product obtained using \#226 and \#236 (123 bp); lane 3, the second PCR product (207 bp); lane M, 25-bp ladder markers (Life Technologies, Rockville, MD, USA); lane 4, EcoRI digest of the clone N[ATPAP $]_{10}$-secFGF/pBS/\#9 (195 bp). Arrowheads indicate the DNA bands having the expected sizes. 